\title{
KAJIAN TEORITIS PENGARUH PARAMETER INTERNAL TERHADAP UNJUK KERJA TURBIN PROPELLER SEBAGAI PEMBANGKIT LISTRIK TENAGA AIR PADA SKALA PICO
}

\author{
Akhmad Nurdin \\ Program Studi Teknologi Pengecoran Logam \\ Politeknik Manufaktur Ceper \\ Email: nurdin@polmanceper.ac.id \\ Dwi Aries Himawanto \\ Jurusan Teknik Mesin \\ Fakultas Teknik Universitas Sebelas Maret \\ Email: dwiarieshimawanto@gmail.com \\ Syamsul Hadi \\ Jurusan Teknik Mesin \\ Fakultas Teknik Universitas Sebelas Maret \\ Email: syamsulhadi@ft.uns.ac.id \\ Febri Budi Darsono \\ Jurusan Teknik Mesin \\ Fakultas Teknik Universitas Negeri Semarang \\ Email: febribudi@mail.unnes.ac.id
}

\begin{abstract}
ABSTRAK
Merancang sebuah turbin propeller membutuhkan pemahaman tentang pengaruh parameter terhadap kinerjanya dan ini memberikan informasi penting agar hasil perancangan menghasilkan kinerja optimal. Jumlah sudu, kemiringan sudu, dan sudut outlet pada bagian tip sudu merupakan parameter internal yang mempengaruhi kinerja dari turbin propeller. Kajian ini bertujuan untuk membahas beberapa parameter internal dari turbin propeller pada penelitian-penelitian yang telah dilakukan. Parameter jumlah sudu dan kemiringan sudu menunjukkan kinerja turbin dipengaruhi oleh gaya aksial yang diterima oleh setiap sudunya. Sedangkan pada parameter sudut outlet bagian tip akan mempengaruhi nilai selisih kecepatan tangential absolute antara inlet dan outlet.
\end{abstract}

Kata kunci: Propeller, Jumlah Sudu, Kemiringan Sudu, Sudut Outlet

\begin{abstract}
Designing a propeller turbine requires an understanding of the influence of parameters on its performance and this will provide important information so that the design results produce optimal performance. The number of blades, the angle of the blade, and the angle of the outlet at the tip of the blade are internal parameters that affect the performance of the propeller turbine. This study aims to discuss some internal parameters of the turbine propeller on studies that have been done. The parameters for the number of blades and the angle of the blade indicate that the performance of the turbine is affected by the axial force received by each blade. Whereas the angle of the outlet at the tip of the blade parameter will affect the value of the absolute tangential difference in velocity between the inlet and outlet.
\end{abstract}

Keywords: Propeller, Number of Blade, Blade Angle, Outlet Angle 


\section{PENDAHULUAN}

Secara geografis Indonesia terletak pada daerah tropis karena dilewati garis katulistiwa, sehingga ketersediaan sumber daya alam sangat melimpah. Salah satu sumber daya alam yang melimpah di Indonesia adalah air [1]. Sumber daya air bersifat bebas emisi polutan dan bersifat berkelanjutan, sehingga dikategorikan sebagai salah satu dari jenis sumber energi terbarukan. Potensi sumber energi air di Indonesia diperkirakan mencapai 75,000 MW, namun baru sekitar 9\% dimanfaatkan sebagai pembangkit listrik tenaga air atau hydropower pada skala kecil sampai skala besar [2]. Berdasarkan daya yang mampu dihasilkan, hydropower dapat diklasifikasikan dalam enam skala, mulai dari skala large sampai skala pico [3] seperti ditunjukkan Tabel 1.

Tabel 1. Klasifikasi hydropower berdasarkan dayanya [3]

\begin{tabular}{cc}
\hline Klasifikasi & Daya \\
\hline Large Scale & lebih $100 \mathrm{MW}$ \\
Medium Scale & antara $10-100 \mathrm{MW}$ \\
Small Scale & antara $1-10 \mathrm{MW}$ \\
Mini Scale & antara $100 \mathrm{~kW}-\mathrm{I} \mathrm{MW}$ \\
Micro Scale & antara $5-100 \mathrm{~kW}$ \\
Pico Scale & dibawah $5 \mathrm{~kW}$ \\
\hline
\end{tabular}

Dalam skala terendah dengan daya yang mampu dihasilkan dibawah $5 \mathrm{~kW}$, pico hydro dapat dihasilkan dengan nilai head atau beda ketinggian sangat rendah [4]. Pada head rendah dengan debit relatif besar, jenis turbin reaksi lebih sesuai untuk diaplikasikan dibandingkan jenis turbin impuls [5]. Salah satu jenis turbin reaksi yang sering digunakan karena mampu bekerja dengan efisiensi tinggi adalah turbin propeller [6]. Sedangkan berdasarkan kriterianya yang ditunjukkan Tabel 2 dibandingkan beberapa tipe turbin lainnya, turbin propeller memiliki keunggulan pada beberapa kriteria dibandingkan dengan tipe turbin lainnya [7].

Tabel 2. Perbandingan turbin berdasarkan kriteria [7]

\begin{tabular}{lccccccc}
\hline \multirow{2}{*}{ Kriteria } & \multicolumn{7}{c}{ Tipe Turbin } \\
\cline { 2 - 8 } & Pelton & Turgo & CrossFlow & Propeller & Francis & Kaplan & PAT \\
\hline Efisiensi-Desain & 0 & 0 & - & + & + & + & 0 \\
Efisiensi-Pembuatan & 0 & 0 & + & - & - & + & - \\
Kontruksi & 0 & 0 & + & + & - & - & - \\
Biaya & 0 & 0 & 0 & + & - & - & - \\
Perawatan-Perbaikan & 0 & 0 & 0 & + & - & - & - \\
Portabilitas & 0 & 0 & 0 & + & + & 0 & 0 \\
Kemampuan-Modularitas & + & + & + & + & + & - & - \\
Ket : 0 = Cukup, + = Baik, - = Kurang & & & & & \\
\hline
\end{tabular}

Gambar 1 menunjukkan konstruksi turbin propeller yang sering digunakan dengan aliran vertikal, terdapat beberapa bagian pokok pada konstruksi tersebut, yaitu runner (turbin), guide vane (sudu pengarah), dan generator yang dihubungkan oleh sebuah poros dengan turbin [8]. Sedangkan Gambar 2 menunjukkan penampang dari turbin propeller dengan beberapa bagiannya. 


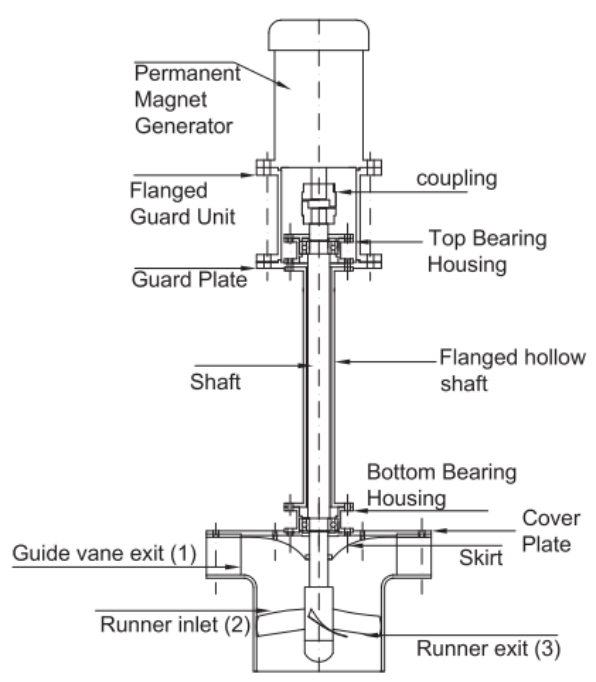

\section{Gambar 1. Konstruksi turbin propeller aliran vertikal [8]}

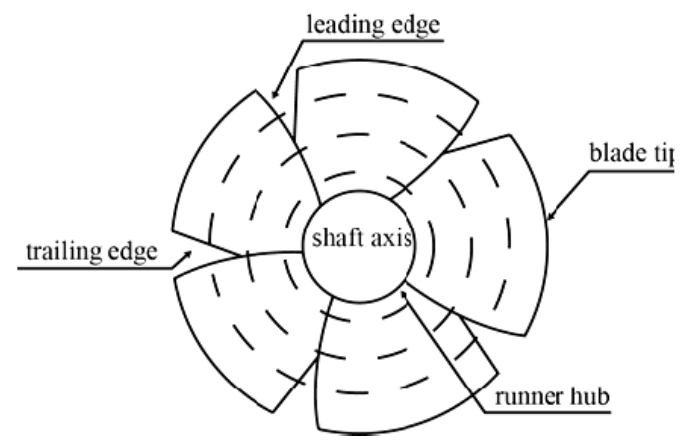

Gambar 2. Penampang turbin propeller [13]

Geometri dari sebuah turbin air akan mempengaruhi kinerjanya, sehingga pemahaman tentang parameter saat perencanaan turbin air akan memberikan informasi terhadap kinerjanya, sehingga dapat menghasilkan perancangan yang optimal dan sesuai rencana [9]. Dasar kinematika aliran air saat menumbuk turbin dapat dianalisa melalui skema segitiga kecepatan seperti yang ditunjukkan Gambar 3 dengan panjang garis mewakili kecepatannya, dan anak panah mewakili arah alirannya [10]. Terdapat beberapa parameter internal dan eksternal turbin propeller yang mempengaruhi kinerjanya. Parameter internal turbin propeller yang mempengaruhi kinerjanya antara lain jumlah sudu [8][11][12][13], kemiringan sudu [11][14][15], dan geometri sudut oulet [10].

Objek kajian ini terletak pada pembahasan pengaruh perubahan parameter-parameter internal turbin propeller terhadap unjuk kerjanya dari beberapa penelitian yang telah dilakukan. Tujuan kajian ini dilakukan untuk mengetahui fenomena yang terjadi pada perubahan parameterparameter internal terhadap kinerjanya, sehingga dapat dipahami informasi tentang pengaruh perubahan parameter tersebut saat merancang turbin propeller. 


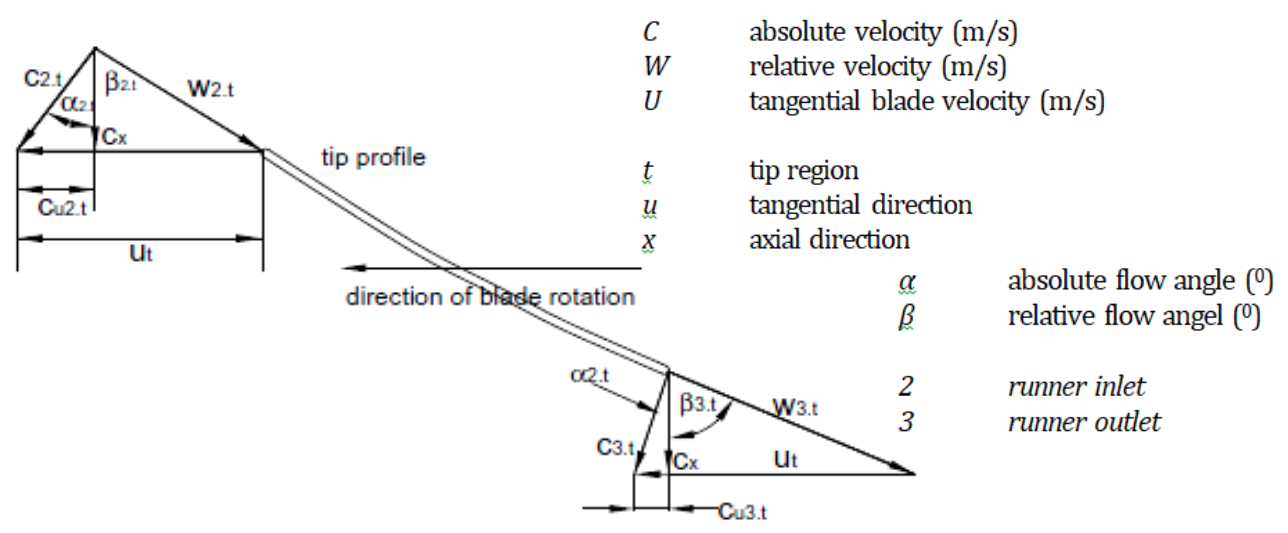

Gambar 3. Diagram segitiga kecepatan turbin propeller [10]

\section{PEMBAHASAN}

Pada sub-bab ini menampilkan kinerja dan fenomena dari beberapa parameter internal turbin propeller berdasarkan penelitian-penelitian yang telah dilakukan, antara lain parameter jumlah sudu, kemiringan sudu, rasio hub/tip turbin, dan geometri sudut oulet.

\subsection{Pengaruh Jumlah Sudu Terhadap Kinerja Turbin}

Penelitian metode simulasi numerik turbin propeller aliran vertikal dengan plat datar dilakukan oleh Farhan, (2016) menggunakan Computional Fluid Dynamic (CFD) pada kondisi turbin statis dengan perangkat lunak Solidwork 2014 menunjukkan jumlah sudu mempengaruhi nilai torsi. Jumlah sudu yang digunakan pada penelitian ini yaitu 3 sampai 11 buah, masingmasing diuji pada debit 5.61 L/s, 7.3 L/s, 11.1 L/s, dan $12.9 \mathrm{~L} / \mathrm{s}$. Penelitian ini menunjukkan semakin bertambah jumlah sudu sampai jumlah sudu 10 semakin naik nilai torsinya, selain itu pada debit $12.9 \mathrm{~L} / \mathrm{s}$ menunjukkan torsi terbesar dibandingkan debit lainnya. Gambar 4 menunjukkan pada kemiringan sudu $20^{\circ}$ (terhadap axis line) jumlah sudu 10 buah menghasilkan torsi paling optimal, selanjutnya menurun sampai jumlah sudu 11 buah.

Penelitian menggunakan simulasi numerik juga dilakukan oleh Byeon dan Kim, (2013) meneliti pengaruh jumlah sudu terhadap karakteristik turbin propeller pada aliran vertikal menggunakan metode CFD. Level jumlah sudu yang digunakan pada penelitian ini 3, 4, dan 5 buah masing-masing diuji pada kecepatan putaran 100 sampai $400 \mathrm{rpm}$ dengan paremeter bebasnya efisiensi. Gambar 5 secara umum menunjukkan nilai efisiensi turbin meningkat mulai dari 0 rpm dan mencapai titik optimalnya sampai di kecepatan putar $200 \mathrm{rpm}$, selanjutnya menurun sampai dikecepatan putar $400 \mathrm{rpm}$. Selain itu Gambar 5 berdasarkan trendline juga menunjukkan pada jumlah sudu 4 menunjukkan nilai efisiensi tertinggi dibandingkan jumlah sudu 3 dan 5 .

Sedangkan penelitian menggunakan metode eksperimental pada kajian ini membahas penelitian Singh dan Nestmann, (2011), dan Kurniawan dkk., (2019). Penelitian yag dilakukan Singh dan Nestmann, (2011) membandingkan kinerja turbin propeller aliran vertikal pada jumlah sudu 5 dan 6 buah, Gambar 6 menunjukkan hasil penelitian ini dengan kinerja pada jumlah sudu 5 lebih tinggi dibandingkan pada jumlah sudu 6 seperti yang ditunjukkan Gambar 6. Sedangkan pada penelitian yang dilakukan oleh Kurniawan dkk., (2019) membandingkan jumlah sudu terhadap daya listrik pada turbin propeller plat datar dengan aliran horisontal, jumlah sudu yang digunakan 4 sampai 8 buah masing-masing diuji pada debit 0.0053 sampai $0.00114 \mathrm{~m}^{3} / \mathrm{s}$. Hasil 
penelitian ini ditunjkkan Gambar 7 dengan jumlah sudu 6 buah dengan debit $0.00114 \mathrm{~m}^{3} / \mathrm{s}$ menunjukkan hasil paling optimal dibandingkan jumlah sudu dan debit lainnya.

Beberapa kajian tentang jumlah sudu menunjukkan hasil dengan jumlah sudu yang bekerja paling optimal yang berbeda pada setiap penelitian, hal ini disebabkan pada turbin propeller tidak hanya parameter jumlah sudu yang berpengaruh terhadap kinerja turbin, tapi juga terdapat parameter-parameter lainnya yang mempengaruhi. Secara geometri turbin, jumlah sudu akan mempengaruhi celah antar sudu, semakin banyak jumlah sudu maka celah antar sudu akan semakin menyempit [11][12], sehingga setelah mencapai titik optimalnya kinerja turbin akan semakin menurun hal ini disebabkan pada celah antar sudu yang semakin sempit aliran air yang melewati sudu terhambat dan menyebabkan kinerja turbin menurun. Sedangkan sebelum mencapai titik optimal, semakin banyak sudu kinerja turbin akan semakin naik, hal ini disebabkan pada jumlah sudu yang semakin banyak gaya aksial yang diterima turbin akan semakin naik [8].

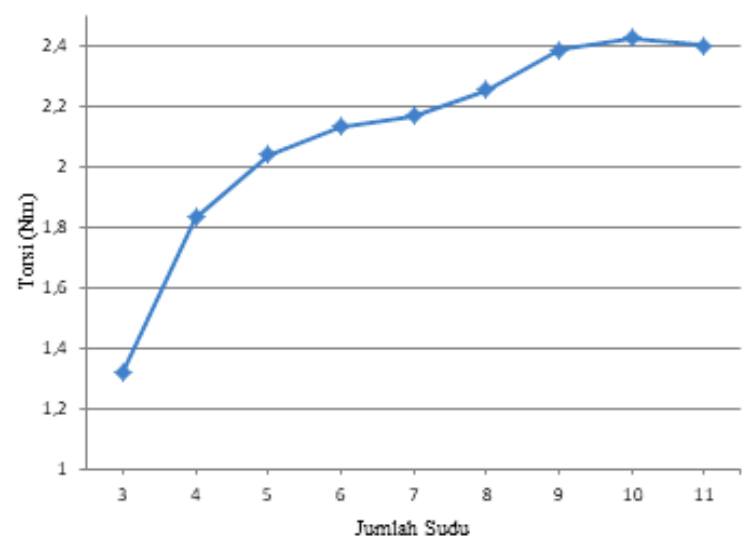

Gambar 4. Grafik hubungan jumlah sudu dengan torsi pada kemiringan sudu $20^{\circ}$ dan debit 12.9 L/s [11]

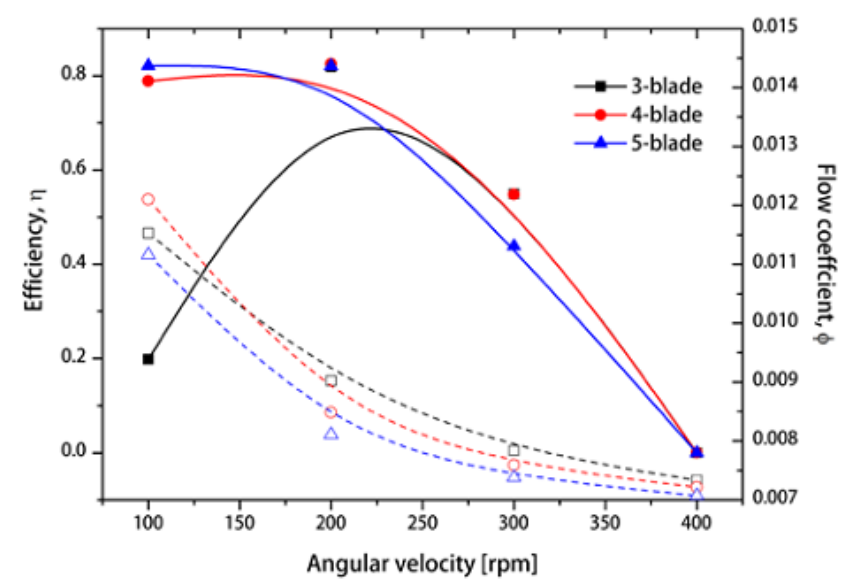

Gambar 5. Efisiensi turbin propeller berdasarkan jumlah sudu [13] 


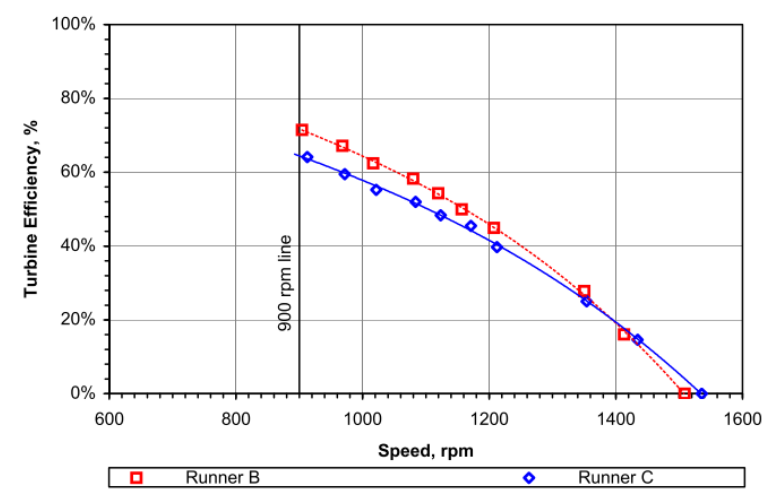

Gambar 6. Efisiensi turbin propeller jumlah sudu 5 (B) dan jumlah sudu 6 (C) [8]

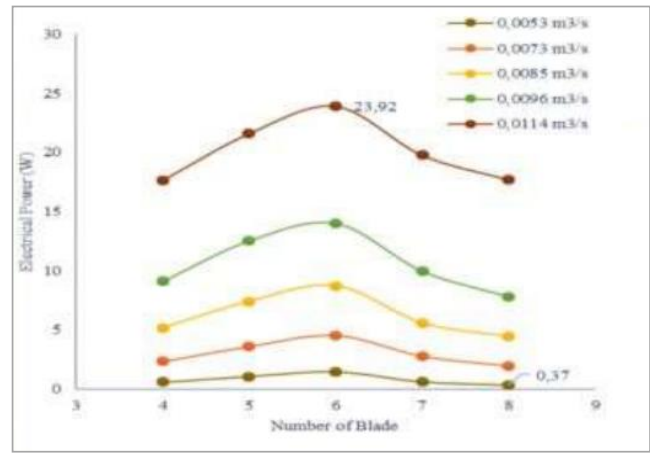

Gambar 7. Hubungan jumlah sudu dengan daya listrik [12]

\subsection{Pengaruh Kemiringan Sudu Terhadap Kinerja Turbin}

Farhan, (2016) melakuakan penelitian metode simulasi numerik turbin propeller aliran vertikal dengan plat datar menggunakan CFD dengan parameter kemiringan sudu, yaitu pada kemiringan $50^{\circ}, 60^{\circ}, 70^{\circ}$, dan $80^{\circ}$ dengan sketsa kemiringan ditunjukkan Gambar 8. Setiap variasi parameter kemiringan diuji pada debit 5.61 L/s, 7.3 L/s, 11.1 L/s, dan $12.9 \mathrm{~L} / \mathrm{s}$. Seperti pada Tabel 3, penelitian ini menunjukkan torsi turbin mencapai titik optimalnya pada kemiringan $60^{\circ}$, selanjutnya menurun pada kemiringan $70^{\circ}$ dan $80^{\circ}$. Selain itu, penelitian ini juga menunjukkan semakin besar debit air, semakin besar torsi yang dihasilkan oleh turbin.

Penelitian pengaruh kemiringan sudu terhadap kinerja turbin propeller juga dilakukan dengan metode eksperimental, pada kajian ini membahas penelitian yang dilakukan Shalih dkk., (2019), dan Shantika dkk., (2013). Penelitian yang dilakukan Shalih dkk., (2019) membandingkan kemiringan sudu terhadap daya listrik yang dihasilkan pada aliran horisontal menggunakan turbin propeller plat datar, kemiringan sudu yang digunakan yaitu $10^{\circ}, 30^{\circ}, 45^{\circ}, 60^{\circ}$ dan $75^{\circ}$ dengan sketsa kemiringan ditunjukkan Gambar 8 dengan setiap derajat kemirinagn diuji pada debit 0.0053 sampai $0.00114 \mathrm{~m}^{3} / \mathrm{s}$. Hasil penelitian ini ditunjkkan Gambar 9 dengan kemiringan sudu $30^{\circ}$ dengan debit $0.00114 \mathrm{~m}^{3} / \mathrm{s}$ menunjukkan hasil paling optimal dibandingkan jumlah sudu dan debit lainnya. Sedangkan Shantika dkk., (2013) merancang PLTA kecil dengan turbin propeller plat datar dengan aliran vertikal, parameter yang digunakan adalah kemiringan sudu dengan level 20, 30, 40, dan 50 derajat setiap levelnya diuji dengan debit $2.2 \mathrm{~L} / \mathrm{s} ; 3.7 \mathrm{~L} / \mathrm{s}$; dan $6.2 \mathrm{~L} / \mathrm{s}$. Gambar 10 menunjukkan daya poros paling optimal terjadi pada level kemiringan $30^{\circ}$ selanjutnya menurun 
pada kemiriangan $40^{\circ}$ dan $50^{\circ}$, selain itu penelitian ini menunjukkan semakin besar debit maka daya poros akan semakin naik.

Sama seperti pada parameter jumlah sudu, pada parameter kemiringan sudu juga menunjukkan level kemiringan sudu optimal yang berbeda pada setiap penelitian hal ini disebabkan pada turbin propeller tidak hanya parameter kimiringan sudu yang berpengaruh terhadap kinerja turbin, tapi juga terdapat parameter-parameter lainnya yang mempengaruhinya. Kemiringan sudu akan mempengaruhi bentuk dan geometri dari turbin, yaitu celah antar sudu turbin semakin kecil derajat kemiringan sudu maka celah antar sudu semakin sempit [11]. Setelah mencapai titik optimalnya, kinerja turbin akan semakin menurun hal ini disebabkan pada level kemiringan sudu sesudah mencapai titik optimalnya aliran air tidak sepenuhnya menumbuk sudu karena kemiringan sudu semakin menjauhi garis tegak lurus terhadap axis line atau aliran airnya sehingga gaya tangensial pada turbin semakin menurun [14][15]. Sedangkan sebelum mencapai titik optimalnya kinerja turbin menunjukkan tren kenaikan, hal ini disebabkan pada kemiringan sudu sebelum mencapai titik optimalnya celah antar sudu semakin menyempit sehingga aliran air terhambat dan menurunkan kinerja [11][14].

\subsection{Pengaruh Sudut Outlet Terhadap Kinerja Turbin}

Singh dan Nestmann, (2010) melakukan penelitian secara eksperimental pengaruh kelengkungan sudut outlet bagian tip pada turbin propeller aliran vertikal dengan 5 buah sudu. Penelitian ini membandingkan kinerja turbin sebelum dan sesudah dimodifikasi. Spesifikasi turbin sebelum dimodifikasi ditunjukkan Tabel 4, dengan dh/D merupakan rasio diameter hub dengan tip, $\alpha_{2 \mathrm{t}}$ sudu inlet bagian tip, $\alpha_{2 \mathrm{~h}}$ sudut inlet bagian hub, dan $\mathrm{Z}$ jumlah sudu.

Modifikasi sudut outlet pada runner A seperti ditunjukkan Tabel 5 dilakukan 2 kali yaitu $85^{\circ}$ menjadi $77^{\circ}$ dan dari $77^{\circ}$ menjadi $74^{\circ}$, sedangkan pada runner B dilakukan sekali modifikasi pada bagian outlet yaitu $75^{\circ}$ menjadi $70^{\circ}$. Skema segitiga kecepatan masing-masing modifikasi sudut outlet tersebut ditunjukkan Gambar 12, secara umum pada penelitian ini menunjukkan semakin kecil nilai sudut outlet bagian tip akan meningkatkan nilai efisensi. Selain itu, berdasarkan Gambar 12 dengan parameter independent yang sama menunjukkan runner B dengan modifikasi $70^{\circ}$ menunjukkan nilai eifisiensi tertinggi dibandingkan modifikasi pada runner A.

Pada perubahan sudut outlet pada sudu propeller akan mengubah skema segitiga kecepatan (Gambar 12). Hal yang perlu diperhatikan dalam menganalisa segitiga kecepatan pada penelitian adalah nilai perubahan gaya tangensial absolute velocity pada inlet dan outlet $\left(\triangle \mathrm{C}_{\mathrm{U}}\right)[10]$. Sehingga pada analisa segitiga kecepatan semakin besar nilai $\triangle \mathrm{C}_{\mathrm{U}}$ maka kinerja dari turbin semakin baik, hal ini disebabkan semakin besar nilai $\triangle \mathrm{C}_{\mathrm{U}}$ maka energi yang diserap oleh turbin semakin besar pula. Tabel 5 menunjukkan nilai $\left(\triangle \mathrm{C}_{\mathrm{U}}\right)$ pada runner $\mathrm{A}$ dan runner $\mathrm{B}$ dengan modifikasi masing-masing sudut outlet.

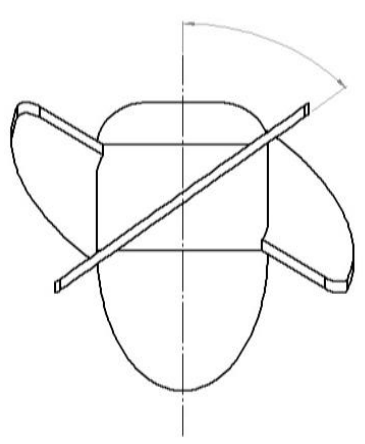

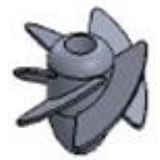

Sudut kemiringan sudu $50^{\circ}$

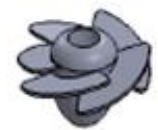

Sudut kemiringan sudu $70^{\circ}$

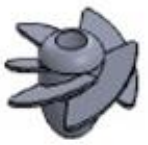

Sudut kemiringan sudu $60^{\circ}$

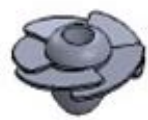

Sudut kemiringan sudu $80^{\circ}$

Gambar 8. Sketsa kemiringan sudu [11] 


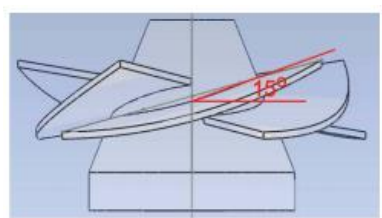

Sudut kemiringan sudu $15^{\circ}$

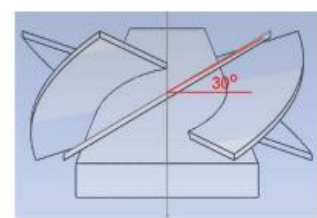

Sudut kemiringan sudu $30^{\circ}$

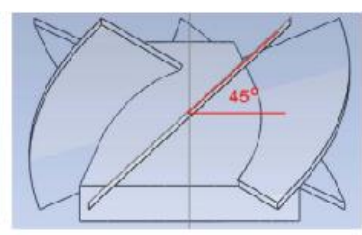

Sudut kemiringan sudu $45^{\circ}$

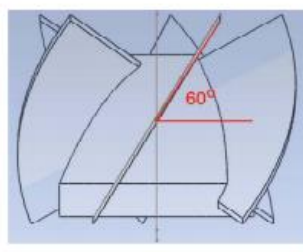

Sudut kemiringan sudu $60^{\circ}$

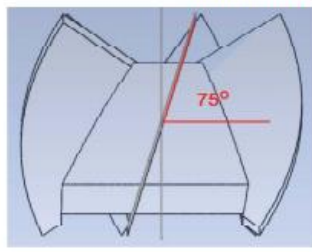

Sudut kemiringan sudu $75^{\circ}$

Gambar 9. Sketsa kemiringan sudu [14]

Tabel 3. Hasil penelitian kemiringan sudu terhadap torsi turbin [11]

\begin{tabular}{ccccc}
\hline \multirow{2}{*}{ Debit (L/s) } & \multicolumn{4}{c}{ Kemiringan Sudu } \\
\cline { 2 - 5 } & $50^{\circ}$ & $60^{\circ}$ & $70^{\circ}$ & $80^{\circ}$ \\
\hline 5.6 & $0.367 \mathrm{Nm}$ & $0.402 \mathrm{Nm}$ & $0.349 \mathrm{Nm}$ & $0.280 \mathrm{Nm}$ \\
7.3 & $0.623 \mathrm{Nm}$ & $0.684 \mathrm{Nm}$ & $0.593 \mathrm{Nm}$ & $0.476 \mathrm{Nm}$ \\
11.1 & $1.442 \mathrm{Nm}$ & $1.581 \mathrm{Nm}$ & $1.372 \mathrm{Nm}$ & $1.100 \mathrm{Nm}$ \\
12.9 & $1.947 \mathrm{Nm}$ & $2.134 \mathrm{Nm}$ & $1.854 \mathrm{Nm}$ & $1.487 \mathrm{Nm}$ \\
\hline
\end{tabular}

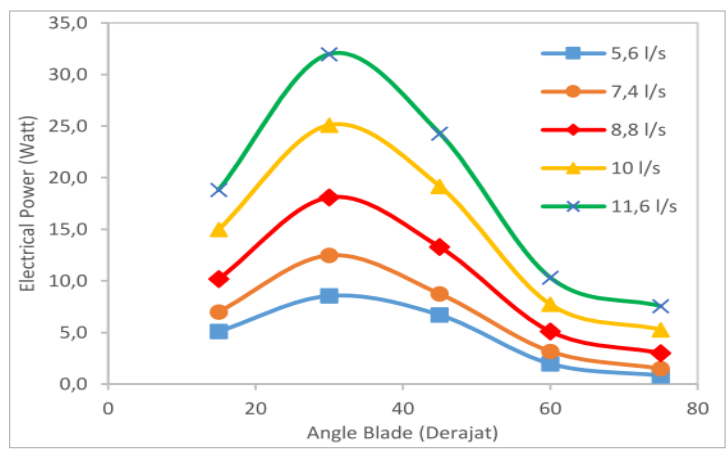

Gambar 10. Hubungan kemiringan sudu dengan daya listrik [14] 


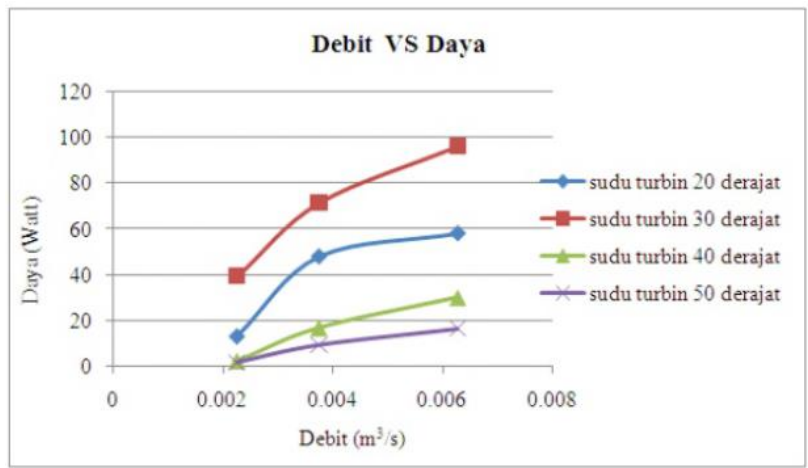

Gambar 11. Hubungan debit air dan kemiringan sudu dengan daya poros [15]

Tabel 4. Spesifikasi runner (turbin) sebelum dimodifikasi [10]

\begin{tabular}{ccccc}
\hline Parameter & $\mathbf{d h} / \mathbf{D}$ & $\boldsymbol{\alpha}_{\mathbf{2 h}}\left({ }^{\mathbf{0}}\right)$ & $\boldsymbol{\alpha}_{\mathbf{2 t}}\left(^{(\mathbf{}}\right)$ & $\mathbf{Z}$ \\
\hline Runner A & 0.25 & 71.8 & 38 & 5 \\
Runner B & 0.3 & 68.4 & 37.2 & 5
\end{tabular}

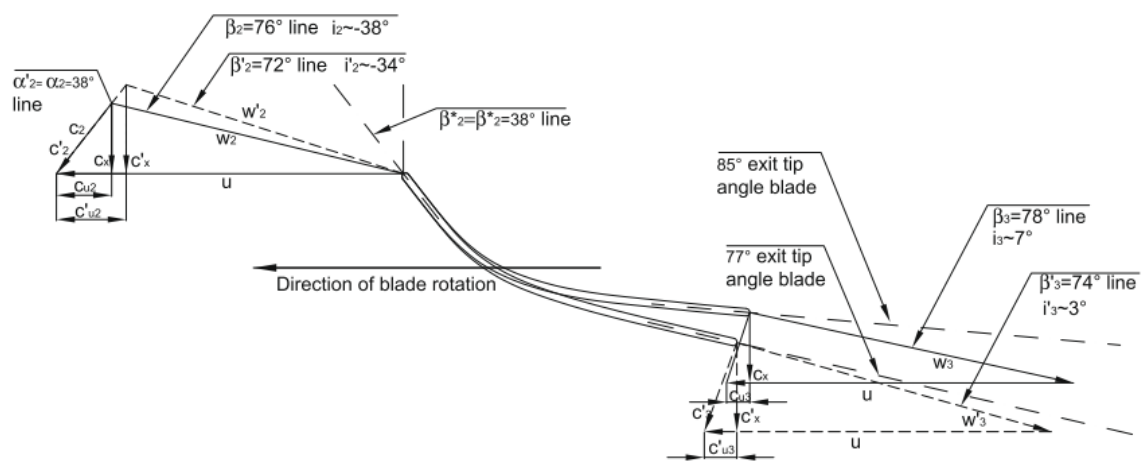

(a)

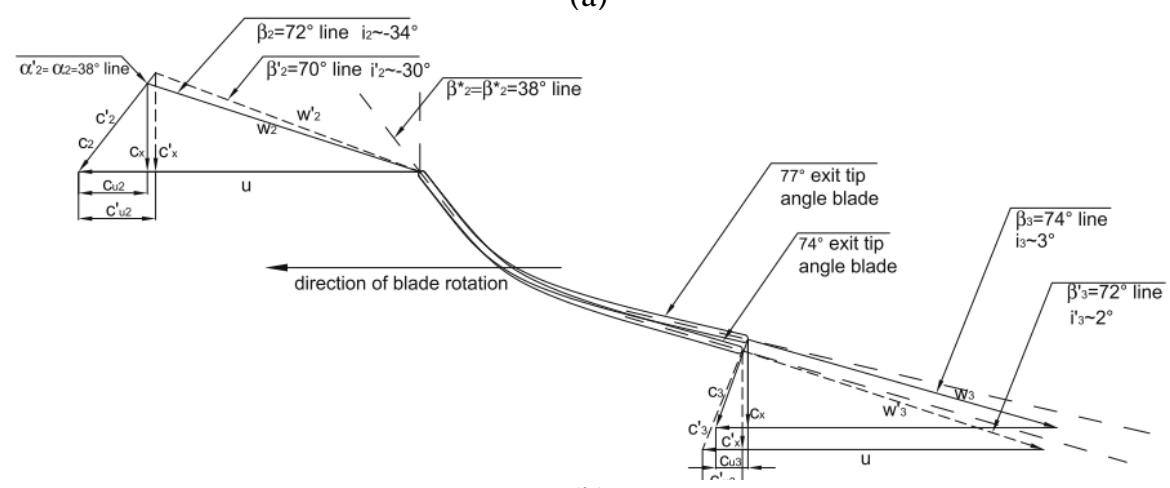

(b) 


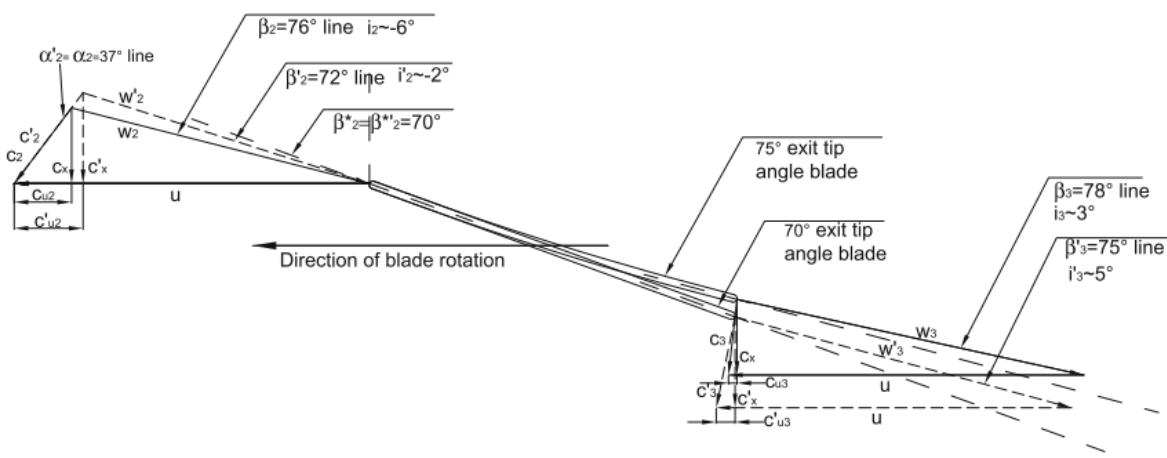

(c)

Gambar 12. Skema segitiga kecepatan bagain tip sebelum dan sesudah modifikasi sudut outlet pada runner A (a) $85^{\circ}-77^{\circ}$ (b) $77^{\circ}-7^{\circ}$ dan pada runner B (c) $75^{\circ}-70^{\circ}$ [10]

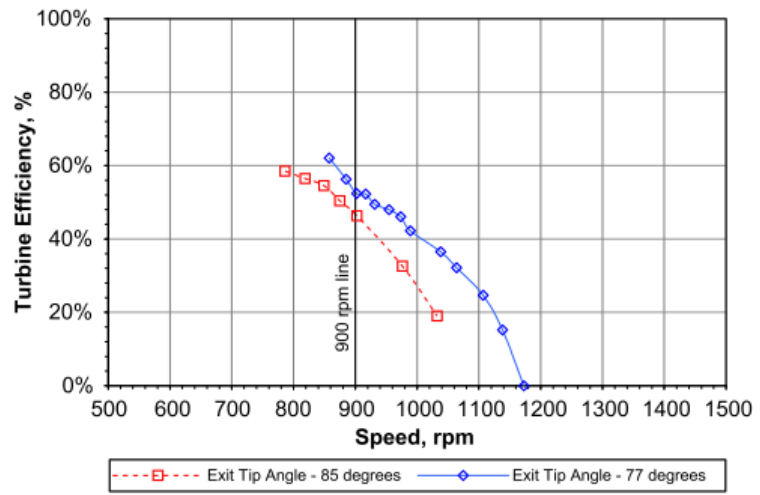

(a)

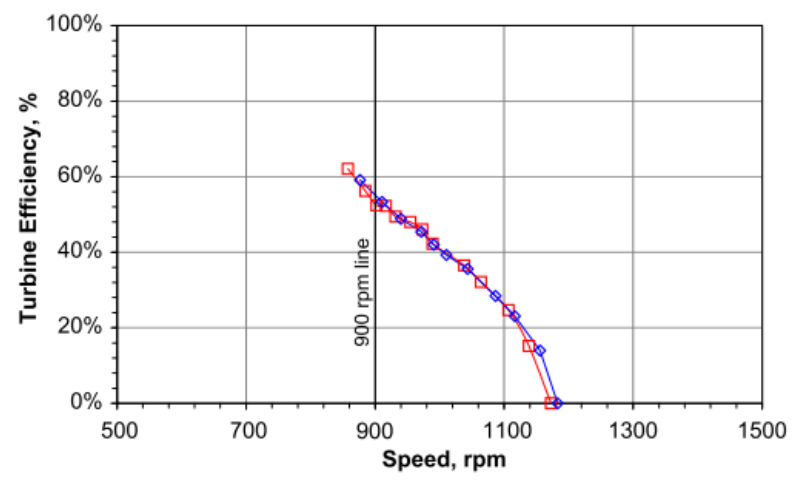

$\square \square$ Exit Tip Angle - 77 degrees $\frown$ - Exit Tip Angle - 74 degrees

(b) 


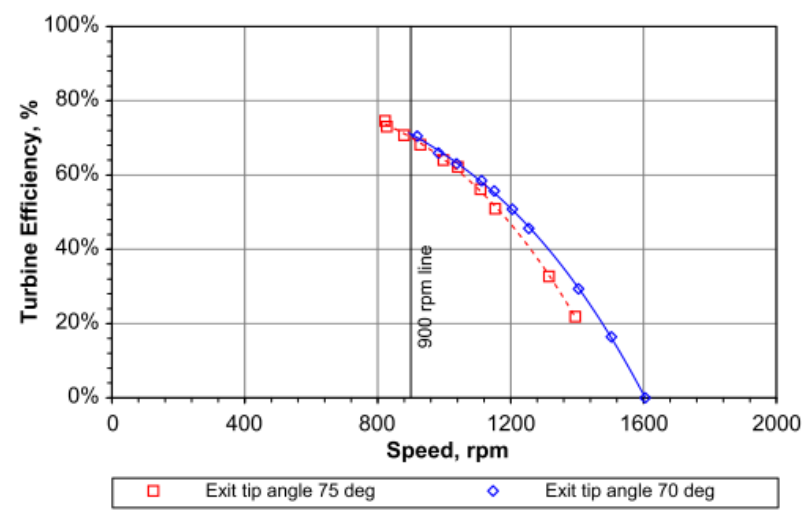

(c)

Gambar 13. Efisiensi turbin sebelum dan sesudah modifikasi sudut outlet pada runner A (a) $85^{\circ}-{77^{\circ}}^{\circ}$ (b) $77^{\circ}-74^{\circ}$ dan pada runner $B$ (c) $75^{\circ}-70^{\circ}[10]$

Tabel 5. Spesifikasi runner (turbin) sebelum dimodifikasi [10]

\begin{tabular}{ccc}
\hline Runner & Sudut Outlet (tip) & $\left(\Delta \mathbf{C}_{\mathrm{u}}\right)$ \\
\hline \multirow{3}{*}{ Runner $A$} & $85^{\circ}$ & 0.86 \\
& $77^{\circ}$ & 0.99 \\
& $74^{\circ}$ & 1.00 \\
\hline \multirow{2}{*}{ Runner B } & $75^{\circ}$ & 1.28 \\
& $70^{\circ}$ & 1.31 \\
\hline
\end{tabular}

\section{KESIMPULAN}

Pemaparan kajian teoritis tentang pengaruh parameter internal turbin propeller dari beberapa penelitian telah dilakukan secara metode simulasi numerik maupun metode eksperimental. Parameter internal seperti jumlah sudu, kemiringan sudu, dan sudut outlet pada bagian tip secara langsung mempengaruhi kinerja turbin propeller.

Parameter jumlah sudu menunjukkan semakin banyak jumlah sudu gaya aksial yang diterima turbin akan semakin naik, namun naiknya gaya aksial yang diterima turbin tidak selalu menaikkan kinerja turbin propeller. Dalam batas jumlah sudut tertentu kinerja turbin propeller dapat menurun, hal ini disebabkan semakin bertambah sudu, semakin kecil celah antar sudu sehingga aliran air melewati turbin terhambat.

Acuan sudut sebagai parameter kemiringan sudu setiap peneliti bisa berbeda, hal ini berkaitan dengan referensi yang digunakan sebagai rujukan. Kemiringan sudu secara langsung akan mempengaruhi posisi sudu terhadap garis horisontal berdasarkan sumbu axis. Posisi sudu yang semakin mendekati ke garis horisontal, gaya aksial yang diterima sudu akan semakin naik, namun hal ini tidak selalu menaikkan kinerja turbin. Pada batas kemiringan sudu tertentu kinerja turbin propeller dapat menurun, hal ini disebabkan semakin mendekati garis horisontal, semakin kecil celah antar sudu sehingga aliran air melewati turbin terhambat. 
Pada parameter sudut outlet pada bagian tip, dengan analisa menggunakan segitiga kecepatan menunjukkan semakin kecil sudut outlet pada bagian tip maka nilai $\triangle C_{u}$ akan semakin meningkat. Nilai $\triangle C_{u}$ menunjukkan besarnya energi yang mampu diserap oleh turbin, semakin besar nilai $\triangle C_{u}$ semakin besar baik pula kinerja dari turbin.

\section{DAFTAR PUSTAKA}

[1] Global Environment Facility, Indonesia: Integrated Micro-hydro Development and Application Program (IMIDAP). United Nations Development Programme (UNDP), 2010.

[2] P. Erinofiardi, Gokhale, A. Date, and A. Akbarzadeh, "A review on micro hydropower in Indonesia," in 1st International Conference on Energy and Power, ICEP2016, 2017, vol. 110, no. December 2016, pp. 316-321.

[3] A. Nurdin, "Optimalisasi Transmisi PLTA - Pico Hydro sebagai Penunjang Konversi Energi Mekanik Menjadi Listrik,” Universitas Sebelas Maret, Surakarta, 2016.

[4] A. Nurdin and D. A. Himawanto, "KAJIAN TEORITIS UJI KERJA TURBIN ARCHIMEDES SCREW PADA HEAD RENDAH," Simetris, vol. 9, no. 2, pp. 783-796, 2018.

[5] S. J. Williamson, B. H. Stark, and J. D. Booker, "Low head pico hydro turbine selection using a multi-criteria analysis," Renew. Energy, vol. 61, pp. 43-50, 2014.

[6] D. Kilama, "Review of small hydropower technology," Renew. Sustain. Energy Rev., vol. 26, pp. 515-520, 2013.

[7] B. Ho-Yan, "Design of a Low Head Pico Hydro Turbine for Rural Electrification in Cameroon," The University of Guelph, 2012.

[8] P. Singh and F. Nestmann, "Experimental investigation of the in fl uence of blade height and blade number on the performance of low head axial fl ow turbines," Renew. Energy, vol. 36, no. 1, pp. 272-281, 2011.

[9] R. Balaka, A. Rachman, and J. Delly, "Blade Number Effect for A Horizontal Axis River Current Turbine at A Low Velocity Condition Utilizing A Parametric Study with Mathematical Model of Blade Element Momentum," J. Clean Energy Technol., vol. 2, no. 1, pp. 1-5, 2014.

[10] P. Singh and F. Nestmann, "Exit blade geometry and part-load performance of small axial flow propeller turbines : An experimental investigation," Exp. Therm. Fluid Sci., vol. 34, no. 6, pp. 798-811, 2010.

[11] A. P. Farhan, "Optimalisasi Desain Turbin PLTA Pico- Hydro Untuk Meningkatkan Efisiensi Daya Dengan Bantuan Software CFD Dan Konsep Reverse Engineering," Universitas Sebleas Maret, 2016.

[12] R. Kurniawan, D. A. Himawanto, and P. J. Widodo, "The performance of numbers of blade towards picohydro propeller turbine," in TICATE 2018, 2019, pp. 3-8.

[13] S. Byeon and Y. Kim, "Influence of Blade Number on the Flow Characteristics in the Vertical Axis Propeller Hydro Turbine," Int. J. Fluid Mach. Syst., vol. Vol. 6, no. no 3, 2013.

[14] A. Shalih, P. J. Widodo, and D. A. Himawanto, "EXPERIMENTAL STUDY THE EFFECT ANGLE OF BLADE ON THE ELECTRICAL POWER OUTPUT OF PROPELLER PICOHYDRO TURBINE Mekanika: Majalah Ilmiah Mekanika 45," Mekanika, vol. 18, no. September, pp. 44-47, 2019.

[15] T. Shantika, "Perekayasaan Pembangkit Listrik Tenaga Air Untuk Penyediaan Listrik Skala Kecil 100 Watt," J. Ind. Res. J., vol. 7, no. 2, 2013. 